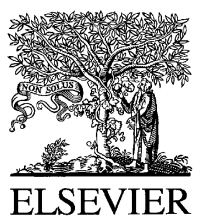

\title{
Enhanced erodibility of fine-grained marine sediments by Hydrobia ulvae
}

\author{
T.J. Andersen ${ }^{\text {a,* }}$, K.T. Jensen ${ }^{\text {b }}$, L. Lund-Hansen ${ }^{\text {b }}$, K.N. Mouritsen ${ }^{\text {b }}$, M. Pejrup ${ }^{\text {a }}$ \\ ${ }^{a}$ Institute of Geography, University of Copenhagen, Øster Voldgade 10, DK-1350 Copenhagen K, Denmark \\ ${ }^{\mathrm{b}}$ Department of Marine Ecology, Institute of Biological Sciences, University of Aarhus, Finlandsgade 14, 8200 Aarhus, Denmark
}

Received 1 June 2001; accepted 18 February 2002

\begin{abstract}
The common mud snail Hydrobia ulvae is a widespread and dominant deposit feeder on fine-grained substrata along the European Atlantic coastline. Previous studies have shown that mud snail activities such as grazing, faecal pellet production and mucous production may influence physical properties of the surface sediment layer and thus depositional and erosional processes. To quantify the influence of Hydrobia density on key parameters such as erosion threshold and erosion rate, a shortterm laboratory experiment was conducted. Snails were placed on fine-grained sediment at densities of 10000 and 50000 ind $\mathrm{m}^{-2}$ and erosion experiments were carried out one, three and five days after establishment of the sediment beds. Controls without $H$. ulvae were treated the same way. The presence of $H$. ulvae significantly increased the erosion rate and decreased the erosion threshold compared to snail-free control plots. The erosion rate was increased by a factor of 2 to 4 when H. ulvae were present and showed stronger influence by the snail than the erosion threshold. Snail density did not affect the erosion threshold,

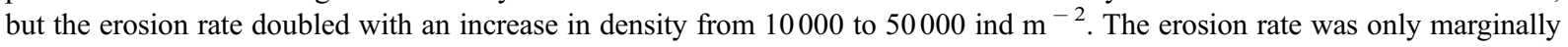
different after one day but the difference increased over time and the erosion rate was significantly different for all treatments after five days. No significant time dependence was observed for the erosion threshold. The results generally confirm results obtained in situ and differences can be related to different hydrodynamic conditions under field and laboratory conditions.

(c) 2002 Elsevier Science B.V. All rights reserved.
\end{abstract}

Keywords: Erodibility; Cohesive sediment; Hydrobia ulvae; Faecal pellet; Erosion threshold; Erosion rate; Mudflat

\section{Introduction}

Biotic factors/processes may play an important role in mediating the deposition and erosion of fine-grained sediment (e.g. Rhoads, 1974; Yingst and Rhoads,

\footnotetext{
${ }^{*}$ Corresponding author.

E-mail address: tja@geogr.ku.dk (T.J. Andersen).
}

1978; Nowell et al., 1981; Grant and Gust, 1987; Paterson, 1989). Several studies have demonstrated that bacteria, benthic diatoms and some macrozoobenthic organisms may modify the erosion threshold of soft-bottom substrata (Paterson, 1989; Underwood and Paterson, 1993; Yallop et al., 1994; Austen et al., 1999; Tolhurst et al., 1999) and some have also attempted to quantify erosion rates of cohesive sediments (Amos et al., 1992, 1996, 1997; Sutherland et al., 1998; Willows et al., 1998; Andersen, 2001a). 
However, for most of the dominant organisms from fine-grained sediments we do not yet have solid data indicating how and to what extent the erodibility of the bed is affected directly and indirectly by the presence of the different species. The common mud snail Hydrobia ulvae is a widespread deposit feeder at fine-grained sediments on European intertidal flats and an evaluation of the effect of this species on the erodibility of the bed is therefore of major importance. The snail may occur in densities of up to about 300000 individuals $\mathrm{m}^{-2}$ (Blanchard et al., 1997; Austen et al., 1999; Jensen, 1992; Lillebø et al., 1999). Some studies (Blanchard et al., 1997; Andersen, 2001a) have indicated that H. ulvae increase the erodibility of their substrata. Not only do the snailshells themselves increase the roughness of the bed, but so does the surface tracking caused by the feeding activity of the snails (Blanchard et al., 1997). Additionally, faecal pellets egested by the snails are easily eroded, and as more than $80 \%$ (by weight) of the topmost $5 \mathrm{~mm}$ of the bed at intertidal mudflats may consist of such pellets, it may be a significant factor in mediating erodibility (Andersen, 2001a).

The present study set out to quantify the effect of H. ulvae density on both erosion threshold and erosion rate in laboratory experiments and to compare these results with data obtained in the field using identical erosion equipment.

\section{Methods}

\subsection{Experimental design}

Hydrobia ulvae was incubated on cohesive sediment collected at Kongsmark (Danish Wadden Sea; mean grain size: $10 \mu \mathrm{m}$, sand content: $<5 \%$; for site description see Andersen and Pejrup, 2001) at densities corresponding to 10000 and 50000 ind $\mathrm{m}^{-2}$, respectively. Controls without $H$. ulvae were also established using the same sediment. The average length of the snails was $2.7 \mathrm{~mm}(\mathrm{SE}=0.60, \mathrm{~N}=60)$ and the mortality of the snails was virtually zero. Erosion experiments were carried out one, three and five days after incubation ( 13 to $21 \mathrm{~h}, 61$ to $69 \mathrm{~h}$ and 117 to $125 \mathrm{~h}$, respectively) with three replicates at each density, giving a total of 27 erosion experiments.

\subsection{Bed preparation}

The sediment was wet-sieved through a $0.5 \mathrm{~mm}$ mesh in order to retain shells and macrofauna and the slurry was placed in 27 containers with a diameter of $18 \mathrm{~cm}$ (one container for each erosion experiment). The sieving was also carried out in order to destroy any sediment aggregates that may otherwise influence the erodibility. The material was allowed to settle for two hours before snails were placed in the experimental containers and seawater was added until a water depth of $8-10 \mathrm{~cm}$ was reached. This water level was maintained throughout the study and the experimental regime was consequently subtidal. The first erosion experiment was carried out $13 \mathrm{~h}$ after bed preparation. The containers were kept at c. $20{ }^{\circ} \mathrm{C}$ and exposed to artificial light from fluorescent tubes for $14 \mathrm{~h}$ each day.

\subsection{Erosion experiments}

Erosion threshold and erosion rate were determined using the portable EROMES erosion equipment (see Schünemann and Kühl, 1991 and Andersen, 2001a). The instrument consists of a $10 \mathrm{~cm}$ perspex tube which is pressed into the bed. Bed shear stress is generated by a flow induced by a propeller and the suspended sediment concentration (SSC) is monitored by an OBS sensor (optical back-scattering sensor). The propeller revolutions have been converted to bed shear stress by use of a calibration based on erosion of quartz sands with known critical erosion shear stress (same procedure and similar test samples as Schünemann and Kühl, 1991). This type of calibration has been used for all previous EROMES measurements. Based on examination of the Reynolds number during the calibration with quartz sand it was found that a partially smooth flow was present for bed shear stresses below $0.5 \mathrm{~N} \mathrm{~m}^{-2}$, whereas the flow is rough and turbulent for higher bed shear stresses. The bed shear stress was gradually increased by $0.1 \mathrm{~N} \mathrm{~m}^{-2}$ every $5 \mathrm{~min}$. The OBS readings are calibrated by determining the SSC in subsamples withdrawn from the instrument during the erosion experiments. The erosion threshold was determined by the same procedure as Riethmüller et al. (1998) and Andersen (2001a), using plots of erosion rates (30 s running mean) versus applied bed shear stress and a critical 
erosion rate of $0.01 \mathrm{~g} \mathrm{~m}^{-2} \mathrm{~s}^{-1}$. The erosion rates reported here are calculated as the average erosion rate for the six bed shear stress increments of $0.1 \mathrm{~N} \mathrm{~m}^{-2}$ from $0.5 \mathrm{~N} \mathrm{~m}^{-2}$ to $1.0 \mathrm{~N} \mathrm{~m}^{-2}$.

\subsection{Chlorophyll-a, bulk density, organic content and faecal pellet content}

A sediment sample from the top 1 to $2 \mathrm{~mm}$ of the bed was taken for each erosion experiment and was analysed for organic content and faecal pellet content. A second sample consisting of five subsamples of the top $5 \mathrm{~mm}$ of the bed was taken with a $20 \mathrm{~cm}^{3}$ syringe (in total $9.7 \mathrm{~cm}^{3}$ ). This sample was used to determine the chlorophyll-a content, wet and dry bulk density and water content. The chlorophyll-a content was dtermined spectrophotometrically after extraction in $97 \%$ ethanol for $24 \mathrm{~h}$ at $5{ }^{\circ} \mathrm{C}$ in darkness. After centrifugation at $3000 \mathrm{rpm}$ for 10 min, the absorbance of the supernatant at 665 and $750 \mathrm{~nm}$ was measured before and after acidification with $200 \mathrm{~mm}^{3}$ of $1 \mathrm{M} \mathrm{HCl}$. Subsequent calculation of chl-a was based on Parsons et al. (1984). A quantitative estimate of the species composition of the microphytobenthos was not undertaken, but visual inspection of the sediment using light microscopy showed dominance of large epipelic diatoms. The organic content was determined by loss on ignition, LOI, for 2 hours at $550{ }^{\circ} \mathrm{C}$ (DIN 18128).

The faecal pellet content of the bed material and the eroded material was determined by gentle wetsieving of the sample through a $63 \mu \mathrm{m}$ mesh, which retained faecal pellets, shell fragments and sand grains. The two subsamples produced were weighed separately after drying at $105{ }^{\circ} \mathrm{C}$ and the faecal pellet content as weight percentage of the total sample was calculated after correction for the faecal pellet content in the retained material. This content was estimated by visual examination under a microscope and was in the range of $90-95 \%$. The faecal pellet contents are minimum values since small pellets passing through the sieve were excluded.

\section{Statistical analysis}

Statistical analysis of the data was performed using ANOVA and Pearson correlation analysis
(Statistical Package for the Social Sciences; SPSS 10.0 for Windows). All parametric tests were preceded by Levene's test for equality of error variances. If homoscedasticity among samples was rejected $(\mathrm{p}<5 \%)$, data were transformed $(\ln (\mathrm{x})$ or $\arcsin \times 0.5)$ in order to meet the requirement or non-parametric statistics (Kruskal-Wallis test) were used.

\section{Results}

As soon as the snails were introduced at the sediment surface they started to feed on the bed material, creating surface tracks and faecal pellets. The average snail density after 3 and 5 days of feeding was 8800 ind $\mathrm{m}^{-2}$ for an initial density of 10000 ind $\mathrm{m}^{-2}$ and 34500 ind $\mathrm{m}^{-2}$ for an initial density of $50000 \mathrm{~m}^{-2}$. Thus about $12 \%$ and $30 \%$ of the snails had left the sediment surface at the two densities, respectively, and had moved to the walls of the containers. The results reported here should therefore be regarded as representative of natural densities of $H$. ulvae of approximately 9000 and 35000 ind $\mathrm{m}^{-2}$ rather than 10000 and 50000 , respectively.

\subsection{Faecal pellets, chlorophyll-a and wet bulk density}

Although the experimental factors were snail density and 'incubation time', other variables could change between the treatments. Faecal pellet production is directly related to the abundance of snails and the duration of their feeding time. Furthermore, the biomass of microalgae was expected to depend on the grazing intensity and time.

For both treatments with $H$. ulvae, the faecal pellet content was low $(5-10 \%)$ after one day of feeding but increased with time (Two-way ANOVA, $\mathrm{F}_{2,12}=80.0$, $\mathrm{P}<0.001$ ) (Fig. 1). However, a significant statistical interaction occurred between the treatments (Two-way ANOVA, $\left.\mathrm{F}_{2,12}=10.4, \mathrm{P}<0.001\right)$. At 10000 ind $\mathrm{m}^{-2}$ the pellet content increased significantly from day 1 to $3(\mathrm{P}=0.014)$. A slight increase also seemed to take place between day 3 and day 5 but this increase was

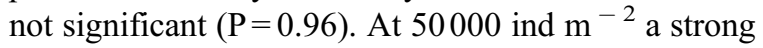
increase was observed between days 1 and 3 $(\mathrm{P}<0.001)$. Pellet content at day 3 was about $70 \%$ and it did not increase further with time. So, the 

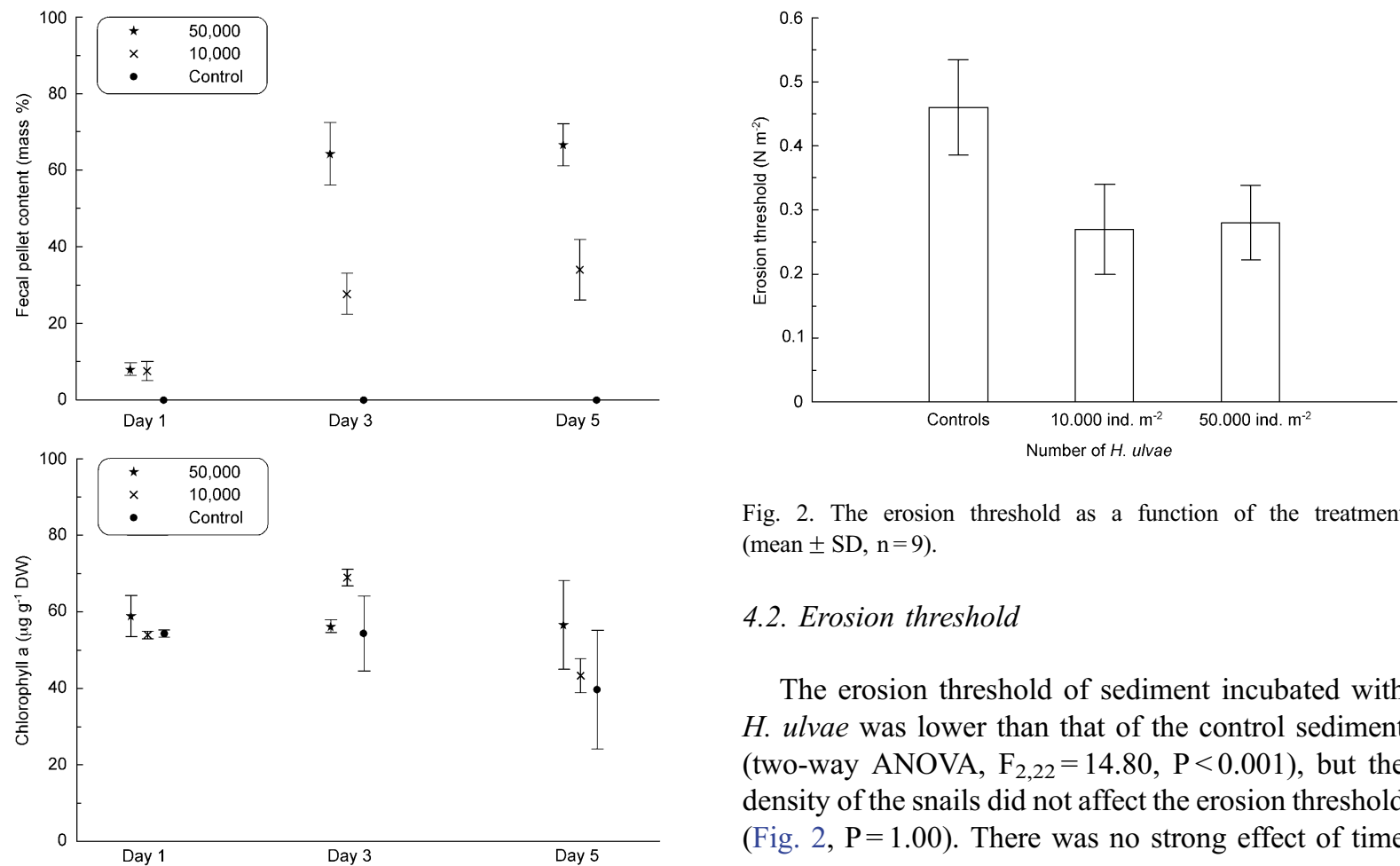

Fig. 2. The erosion threshold as a function of the treatment (mean $\pm \mathrm{SD}, \mathrm{n}=9$ ).

\subsection{Erosion threshold}

The erosion threshold of sediment incubated with H. ulvae was lower than that of the control sediment (two-way ANOVA, $\mathrm{F}_{2,22}=14.80, \mathrm{P}<0.001$ ), but the density of the snails did not affect the erosion threshold (Fig. 2, $\mathrm{P}=1.00$ ). There was no strong effect of time

Fig. 1. Plots of the temporal variation of faecal pellet content and chl $a$ content as a function of the treatment. $\star: 50000$ ind $\mathrm{m}^{-2}, \mathrm{X}$ : 10000 ind $\mathrm{m}^{-2}$, : controls without Hydrobia ulvae. Mean $\pm \mathrm{SD}$, $\mathrm{n}=3$.

treatment interaction was accomplished mainly by a significantly higher pellet content in containers with the higher snail density at both day 3 (Student's ttest, $\left.\mathrm{t}_{4}=5.09, \mathrm{P}=0.007\right)$ and day $5\left(\mathrm{t}_{4}=4.74\right.$, $\mathrm{P}=0.009$ ).

The chlorophyll-a content remained fairly constant throughout the experimental period and no significant differences were observed between the treatments from day 1 to 5 (Fig. 1, Kruskall-Wallis test, $\left.\mathrm{X}_{2}^{2}<4.36, \mathrm{P}>0.11\right)$. Similarly, no dependence on time was observed when the treatments were analysed independently. The wet bulk density varied between 1.23 and $1.65 \mathrm{~g} \mathrm{~cm}^{-3}$ and was not dependent on either treatment or time (Two-way ANOVA, $\mathrm{F}_{2,18}<2.38, \mathrm{P}>0.12$ ) Additionally, the density of the top $5 \mathrm{~mm}$ of the sediment was not related to either the density of $H$. ulvae $\left(\mathrm{r}^{2}=0.00\right.$, $\mathrm{P}>0.05)$ or pellet content $\left(\mathrm{r}^{2}=0.06, \mathrm{P}>0.05\right)$.
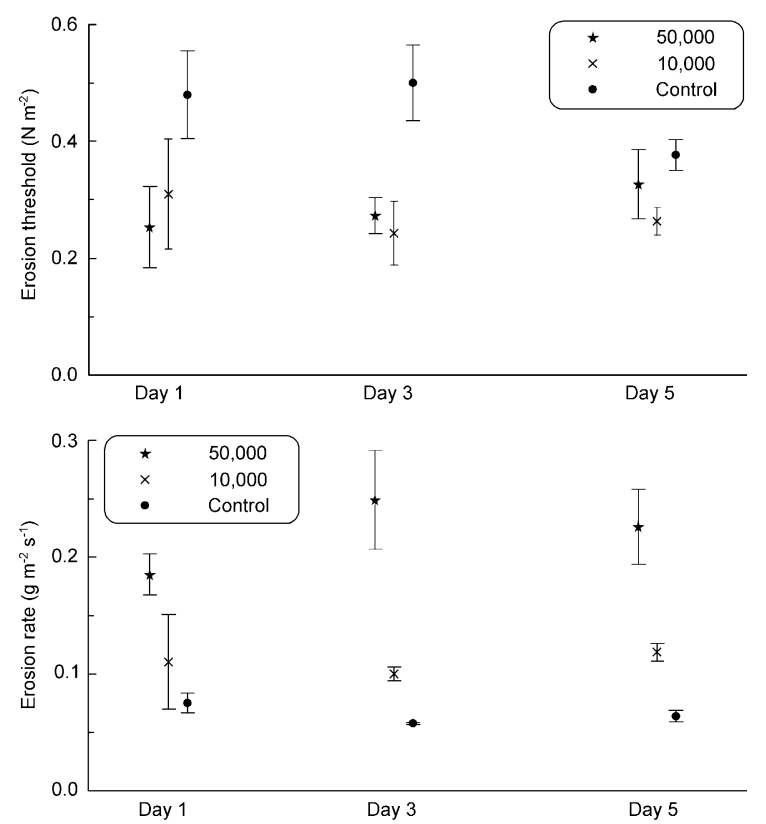

Fig. 3. Plots of the temporal variation of the erosion threshold and erosion rate as a function of the treatment. $\star$ : 50000 ind $\mathrm{m}^{-2}, \mathrm{X}$ : 10000 ind $\mathrm{m}^{-2}$, $\bullet$ : controls without Hydrobia ulvae. Mean \pm SD, $\mathrm{n}=3$. 


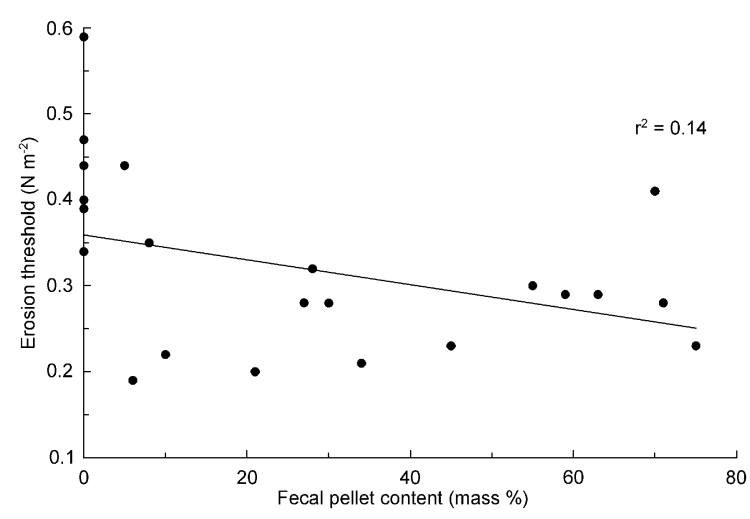

Fig. 4. The erosion threshold plotted as a function of the faecal pellet content of the bed material.

(two-way ANOVA, $\mathrm{F}_{2,22}=0.25, \mathrm{P}=0.78$ ) although erosion threshold shows a decreasing tendency for the control sediment from day 3 to 5 (Fig. 3).

While a significant decline in the erosion threshold was found with snails, there was no significant relationship between the faecal pellet content (mass\%) and the erosion threshold $\left(\mathrm{r}^{2}=0.14, \mathrm{p}>0.05\right)$ (Fig. 4). Nor was there any significant relationship between the erosion threshold and either chl-a content $\left(\mathrm{r}^{2}=0.00\right.$, $\mathrm{p}>0.05)$ or wet bulk density $\left(\mathrm{r}^{2}=0.11, \mathrm{p}>0.05\right)$.

\subsection{Erosion rate}

There were significant differences between the erosion rates for the different treatments for day 3 (one-way ANOVA, $\mathrm{F}_{2,6}=38.6, \mathrm{P}<0.001$ ) and day 5

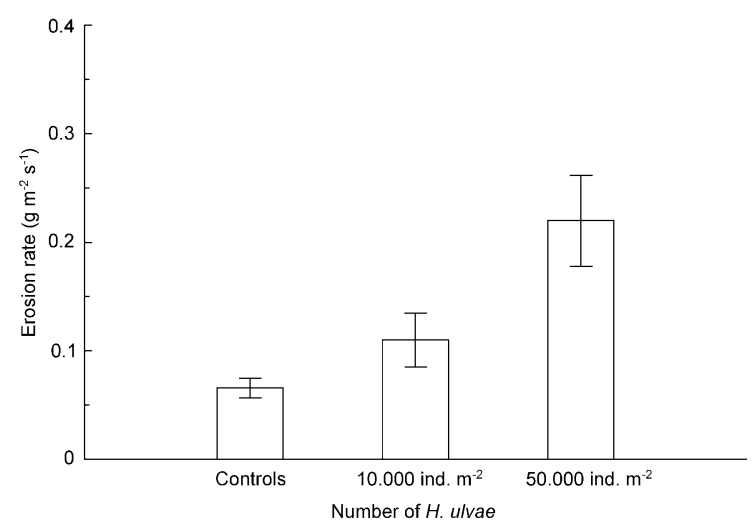

Fig. 5. The average erosion rate at the six $0.1 \mathrm{~N} \mathrm{~m}^{-2}$ bed shear stress increments from $0.5 \mathrm{~N} \mathrm{~m}^{-2}$ to $1.0 \mathrm{~N} \mathrm{~m}^{-2}$ as a function of the treatment (mean $\pm \mathrm{SD}, \mathrm{n}=9$ ).

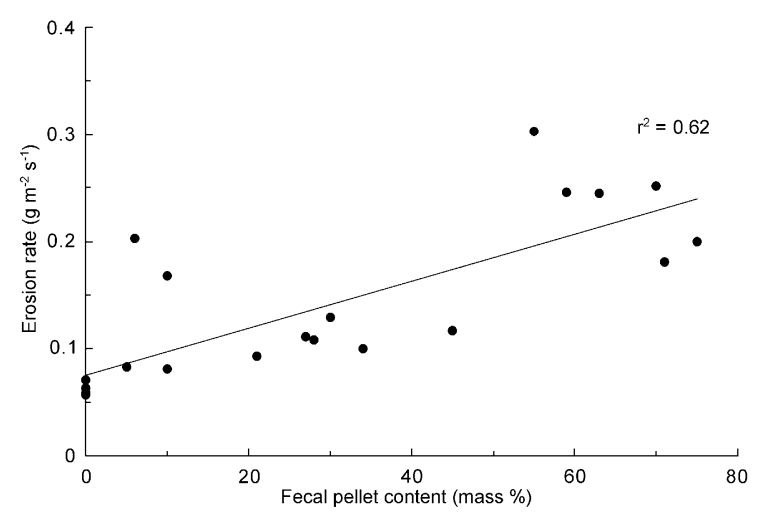

Fig. 6. The average erosion rate at the six $0.1 \mathrm{Nm}^{-2}$ bed shear stress increments from $0.5 \mathrm{~N} \mathrm{~m}^{-2}$ to $1.0 \mathrm{~N} \mathrm{~m}^{-2}$ as a function of the faecal pellet content.

(Kruskall-Wallis test, $\mathrm{X}_{2}{ }^{2}<7.20, \mathrm{P}=0.027$ ), with the erosion rate increasing with increasing snail density (Fig. 3). At 50000 ind $\mathrm{m}^{-2}$ the erosion rate was between 2.5 and 4.3 times higher than that of the controls. The erosion rate did not show any significant temporal variation for any of the treatments.

A strong correlation between the density of $H$. ulvae and the erosion rate was observed $(\mathrm{r}=0.92, \mathrm{P}<0.001$, Fig. 5) as well as a strong correlation between the faecal pellet content and the erosion rate $(r=0.80$, $\mathrm{P}<0.001$, Fig. 6). Partial Pearson correlation was used to test which of the two parameters had the strongest influence on erosion rate. Inspection of the zero order correlation analysis showed that snail density was the main factor controlling the erosion rate (pellet content versus erosion rate, controlling for snail density: $\mathrm{r}=0.41, \mathrm{P}=0.045$; snail density vs erosion rate, controlling for pellet content: $\mathrm{r}=0.84, \mathrm{P}<0.001$ ).

No dependence between chl $a$ content and erosion rate was observed (linear regression: $\mathrm{r}^{2}=0.03, \mathrm{n}=25$ ). Similarly, no dependence on wet bulk density was observed (linear regression: $\mathrm{r}^{2}=0.01, \mathrm{n}=25$ ).

\section{Discussion}

\subsection{Experimental data}

Both erosion threshold and erosion rate were influenced by the presence of $H$. ulvae. Significantly higher erosion thresholds were found for the control 
sediment compared to sediment incubated with snails, but the density of the snails did not seem to affect the erosion thresholds within the range of snail densities applied. At days 1, 3 and 5 the destabilising index $\left(\tau_{\text {crit, control }} / \tau_{\text {crit, snail }}\right)$ was $1.7,1.9$ and 1.3 , respectively. The decline from day 3 to day 5 was due to a decrease in the erosion threshold for the control enclosures probably caused by disruption of the sediment surface by meiofauna (visual inspection of the sediment surface). As the chl-a content was similar in both the control and snail treatments, it seems unlikely that development of biofilm was responsible for the difference measured in erosion threshold. Nor was there any visual evidence of biofilms on the control sediment, although an increased standing stock of microalgae was expected in response to the reduced grazing intensity. All field data from the Kongsmark mudflat have shown lower contents of chl-a at stations with high densities of $H$. ulvae compared to stations with low densities of $H$. ulvae, where biofilms may occasionally form (Austen et al., 1999; Andersen, 2001a). It is also possible that enhanced grazing on the control sediment by meiofauna or micro faunal organisms could control micro algae in the absence of H. ulvae.

The erosion rate increased with snail density. Calculating the destabilising index for the erosion rate $\left(\epsilon_{\text {snail, }} 50000 / \epsilon_{\text {control }}\right)$ gave values of $2.5,4.3$ and 3.5 for the three days. Thus, the biological modification of the erosion rate was stronger than the modification of the erosion threshold. This is in accordance with some earlier observations on the biological mediation of the erodibility of fine-grained sediments (Sutherland et al., 1998; Widdows et al., 1998, 2000; Andersen, 2001a) and highlights the importance of determining both erosion threshold and erosion rate in relation to biological factors. Both parameters are also needed in numerical modelling of cohesive sediment transport - an increasingly important tool for coastal zone management.

The reason for the larger biological modification of the erosion rate than the erosion threshold is that the erosion threshold only reflects the threshold for the surface particles that are easily eroded, e.g. faecal pellets or loose aggregates at surface tracks. Such particles will generally be present even at low densities of macrozoobenthos and the erosion threshold will consequently be low and not decrease signifi- cantly for increasing density of bioturbators. In contrast, the rate at which particles are eroded is strongly dependent on the degree of bioturbation, as the availability of easily eroded aggregates will determine the erosion rate. The amount of easily eroded aggregates will increase with increasing bioturbation as particles become incorporated in low-density aggregates. Additionally, increases in the bed's roughness length, e.g. due to increased surface tracking or increased numbers of shells or faecal pellet mounds, will also cause an increase in current- and wave-induced bed shear stress which will increase the erosion rate.

\subsection{Comparison with field data}

A significant correlation was observed between the faecal pellet content and the erosion rate. However, partial regression analysis indicated that the presence of snails is responsible for a major part of the increase in erosion rate. This contrasts with results from in situ measurements (Andersen, 2001a; Andersen et al., in prep.) demonstrating the importance of faecal pellet content as a controlling factor in the erodibility of the sediment. The present data set was compared with in situ data from Andersen et al. (in prep.) (Fig. 7). Firstly, the in situ data indicate that the erosion rate is well correlated only with faecal pellet content, suggesting that aggregation of bed material is determining the erodibility. Secondly, the erosion rates measured in situ are generally higher than the rates measured in the laboratory, except for beds with low faecal pellet contents. Some of these differences could be due to additional macrozoobenthos in the field (both Heteromastus filiformis and Cerastoderma edule are locally present in high numbers) but the in situ erodibility has been shown to be strongly controlled by H. ulvae (Andersen, 2001a). Therefore, the differences between the results from the laboratory study and field studies are probably caused by differences in the bed structure. In the field, continuous erosion, transport and deposition of fine-grained material take place on intertidal mudflats, creating a surface layer which differs slightly from the surface layer formed in the laboratory experiments. Material is eroded, transported and deposited on the mudflat during almost every tidal cycle and the result is that a surface layer (up to at least $5 \mathrm{~mm}$ thick) consisting of up to $80 \%$ faecal pellet material will normally be 

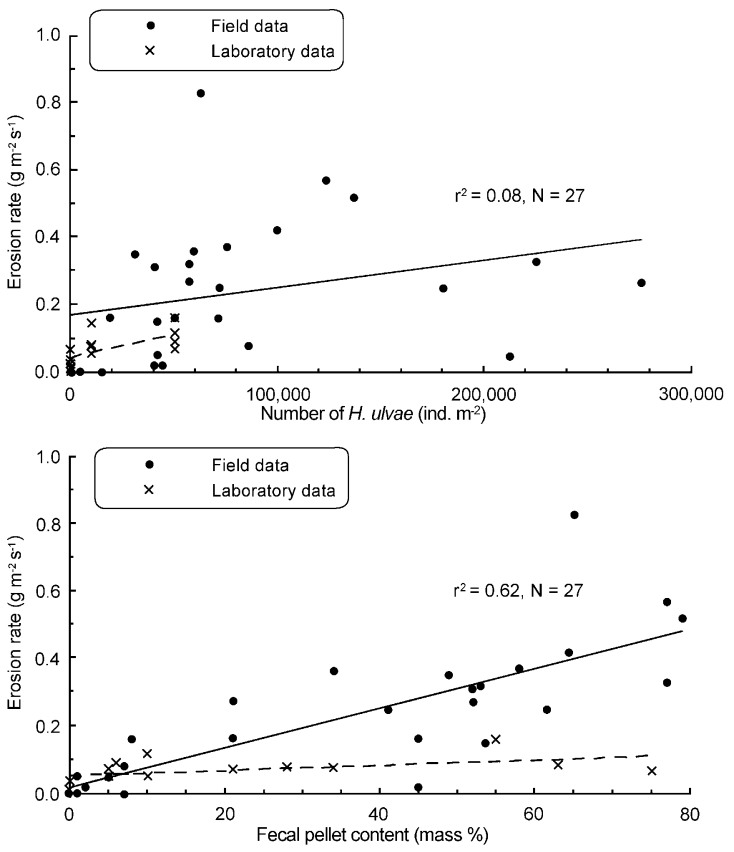

Fig. 7. Comparison of the erosion threshold and the erosion rate for this experiment with data obtained from similar experiments in situ (Andersen et al., in prep.). $\bullet=$ in situ field data; X: this data-set. Solid lines and correlation coefficients: linear regression through field data; dotted lines: linear regression lines through laboratory data. Erosion rates are for an applied bed shear stress of $0.5 \mathrm{~N} \mathrm{~m}^{-2}$.

present. This mobile surface layer is easily eroded and redistributed over some distance by hydrodynamic forces (waves and currents). As a result, the faecal pellet content is not a simple function of snail density and snails are often partly or completely buried in this mobile, pelletised surface layer. The increase in bed roughness normally induced by the snails themselves and their surface tracking is reduced if the snails are buried in faecal pellets and fine-grained material. In that case, the increase in erodibility is related to the faecal pellet content and the thickness of the mobile surface layer. These factors offer the most likely explanation of the results obtained in situ. The mobile surface layer will not be redistributed over the sediment surface in the laboratory experiments (no current and waves) and as a consequence, the increase in roughness induced by shells and surface tracking can be expected to be more important than under field conditions. These differences highlight the importance of field studies as a supplement to studies in the laboratory and indicate that both kinds of studies are needed to gain a detailed knowledge of the system. In nature, it is difficult to assess whether it is the presence of snails or the absence of biofilms that is responsible for the increase in erodibility (e.g., Austen et al., 1999). This study demonstrates that the presence of H. ulvae in itself increases erodibility.

It must be stressed that increased erodibility due to the presence of mud snails does not necessarily result in a net loss of sediment. The strong pelletisation of the surface bed significantly increases the settling velocity of eroded sediment (Edelvang and Austen, 1997; Andersen, 2001b; Andersen and Pejrup, 2002). On fine-grained tidal flats, this increase in settling velocity may result in an increase in the net landward flux of suspended sediment due to the associated increases in settling and scour lag. Consequently, it is possible that the presence of $H$. ulvae on finegrained deposits may increase the deposition rate in spite of the increase in erodibility.

\section{Acknowledgements}

This study was supported by Grant no. 9901789 from the Danish Research Agency. Lars Holmkvist, Niels-Erik Kierstein Nielsen, Anders Krüger Olsen, Rune Munk Pedersen and Sune Riis Sørensen, all students at Institute of Biology, University of Aarhus, are thanked for their practical help during the experiment. We also wish to thank P. Herman and two anonymous reviewers for their comments on the manuscript.

\section{References}

Amos, C.L., Daborn, G.R., Christian, H.A., Atkinson, A., Robertson, A., 1992. In situ erosion measurements on fine-grained sediments from the Bay of Fundy. Mar. Geol. 108, 175-196.

Amos, C.L., Sutherland, T.F., Zevenhuizen, J., 1996. The stability of sublittoral, fine-grained sediments in a subarctic estuary. Sedimentology 43, 1-19.

Amos, C.L., Feeney, T., Sutherland, T.F., Luternauer, J.L., 1997. The stability of fine-grained sediments from the Fraser River Delta. Est. Coast. Shelf Sci. 45, 507-524.

Andersen, T.J., 2001a. Seasonal variation in erodibility of two temperate, microtidal mudflats. Est. Coast. Shelf Sci. 53, 1-12.

Andersen, T.J., 2001b. The role of fecal pellets in suspended sedi- 
ment settling velocities at an intertidal mudflat, the Danish Wadden Sea. In: McAnally, W.H., Mehta, A.J. (Eds.), Coastal and Estuarine Fine Sediment Processes. Elsevier Science, Amsterdam, pp. 387-401.

Andersen, T.J., Pejrup, M., 2001. Suspended sediment transport on a temperate, microtidal mudflat, the Danish Wadden Sea. Mar. Geol. 173, 69-85.

Andersen, T.J., Pejrup, M., 2002. Biological mediation of the settling velocity of bed material eroded from an intertidal mudflat, the Danish Wadden Sea. Est. Coast. Shelf Sci., in press.

Austen, I., Andersen, T.J., Edelvang, K., 1999. The influence of benthic diatoms and invertebrates on the erodibility of an intertidal mudflat, the Danish Wadden Sea. Est. Coast. Shelf Sci. 49, 99-111.

Blanchard, G.F., Sauriau, P.-G., Cariou-Le Gall, V., Gouleau, D., Garet, M.-J., Olivier, F., 1997. Kinetics of tidal resuspension of microbiota: testing the effect of sediment cohesiveness and bioturbation using flume experiments. Mar. Ecol. Prog. Ser. 151, $17-25$.

Edelvang, K., Austen, I., 1997. The temporal variation of flocs and fecal pellets in a tidal channel. Est. Coast. Shelf Sci. 44, $361-367$.

Grant, J., Gust, G., 1987. Prediction of coastal sediment stability from photopigment content of mats of purple sulphur bacteria. Nature 330, 244-246.

Jensen, K.T., 1992. Macrozoobenthos on an intertidal mudflat in the Danish Wadden Sea: comparisons of surveys made in the 1930s, 1940 and 1980s. Helgoländer Meeresunters 46, 363-376.

Lillebø, A.I., Pardal, M.A., Marques, J.C., 1999. Population structure, dynamics and production of Hydrobia ulvae (Pennant) (Mollusca: Prosobranchia) along an eutrophication gradient in the Mondego estuary (Portugal). Act. Oecol. 20, 289-304.

Nowell, A.R.M., Jumars, P.A., Eckman, J.E., 1981. Effects of biological activity on the entrainment of marine sediments. Mar. Geol. 42, 133-153.

Parsons, T.R., Maita, Y., Lalli, C.M., 1984. A Manual of Chemical and Biological Methods for Seawater Analysis. Pergamon, Oxford, $173 \mathrm{pp}$.

Paterson, D.M., 1989. Short-term changes in the erodibility of intertidal cohesive sediments related to the migratory behaviour of epipelic diatoms. Limnol. Oceanogr. 34, 223-234.

Rhoads, D.C., 1974. Organism-sediment relations on the muddy sea floor. Ocean. Mar. Biol. Ann. Rev. 12, 263-300.
Riethmüller, R., Hakvoort, H., Heineke, M., Heymann, K., Kühl, H., Witte, G., 1998. Relating tidal flat surface colour to erosion shear stress. In: Black, K.S., Paterson, D.M., Cramp, A. (Eds.), Sedimentary Processes in the Intertidal Zone. Geol. Soc. London, Spec. Publ., vol. 139, pp. 283-293.

Schünemann, M., Kühl, H., 1991. A device for erosion-measurements on naturally formed, muddy sediments: the EROMESSystem. Report of GKSS Research Centre, Hamburg, GKSS 91/ E/18, 28 pp.

Sutherland, T.F., Grant, J., Amos, C.L., 1998. The effect of carbohydrate production by the diatom Nitzschia curvilineata on the erodibility of sediment. Limnol. Oceanogr. 43, 65-72.

Tolhurst, T.J., Black, K.S., Shayler, S.A., Mather, S., Black, I., Baker, K., Paterson, D.M., 1999. Measuring the in situ erosion shear stress of intertidal sediments with cohesive strength meter (CSM). Est. Coast. Shelf Sci. 49, 281-294.

Underwood, G.J.C., Paterson, D.M., 1993. Seasonal changes in diatom biomass, sediment stability and biogenic stabilization in the Severn Estuary. J. Mar. Biol. Ass. UK 73, 871-887.

Widdows, J., Brinsley, M., Elliot, M., 1998. Use of in situ flume to quantify particle flux (biodeposition rates and sediment erosion) for an intertidal mudflat in relation to changes in current velocity and benthic macrofauna. In: Black, K.S., Paterson, D.M., Cramp, A. (Eds.), Sedimentary Processes in the Intertidal Zone. Geol. Soc., London, Spec. Publ., vol. 139, pp. 85-97.

Widdows, J., Brinsley, M., Salkeld, P.N., Lucas, C.H., 2000. Influence of biota on spatial and temporal variation in sediment erodability and material flux on a tidal flat (Westerschelde, The Netherlands). Mar. Ecol. Prog. Ser. 194, 23-37.

Willows, R.I., Widdows, J., Wood, R.G., 1998. Influence of an infaunal bivalve on the erosion of an intertidal cohesive sediment: A flume and modelling study. Limnol. Oceanogr. 43, $1332-1343$.

Yallop, M.L., De Winder, B., Paterson, D.M., Stal, L.J., 1994. Comparative structure, primary production and biogenic stabilization of cohesive and non-cohesive marine sediments inhabited by microphytobenthos. Est. Coast. Shelf Sci. 39, 565-582.

Yingst, J.Y., Rhoads, D.C., 1978. Seafloor stability in central Long Island Sound: part II. Biological interactions and their potential importance of seafloor erodibility. In: Wiley, M.L. (Ed.), Estuarine Interactions. Academic Press, New York, pp. 245-260. 